\title{
SPRAWOZDANIE Z SYMPOZJUM STOWARZYSZENIA KATECHETYKÓW POLSKICH „ŚWIATOWE DNI MŁODZIEŻY WYDARZENIEM KATECHETYCZNYM" (CZĘSTOCHOWA 23-24 WRZEŚNIA 2014)
}

W dniach 23-24 września 2014r. w Centrum Duchowości Księży Jezuitów odbywało się doroczne sympozjum Stowarzyszenia Katechetyków Polskich (SKP). Zgodnie z ustaleniami sprzed roku, zagadnieniem podejmowanym w referatach oraz panelu dyskusyjnym były „Światowe Dni Młodzieży wydarzeniem katechetycznym”. Po uroczystym otwarciu sympozjum przewodniczący Stowarzyszenia - ks. prof. dr hab. Zbigniew Marek SJ powitał wszystkich oraz złożył gratulacje nowo mianowanym profesorom. Należeli do nich (w kolejności alfabetycznej: ks. prof. dr hab. Ryszard Czekalski, ks. prof. dr hab. Stanisław Dziekoński, ks. prof. dr hab. Piotr Tomasik oraz p. prof. dr hab. Anna Zellma) ${ }^{1}$. Przewodniczący SKP wyraził także wdzięczność wobec ks. dr hab. Radosława Chałupniaka za prowadzenie strony internetowej Stowarzyszenia.

W pierwszej części sympozjum obradom przewodniczył ks. dr hab. Andrzej Kiciński prof. KUL, zaś referaty wygłosili p. dr Elżbieta Tkocz oraz ks. mgr Adam Spałek $^{2}$. P. E. Tkocz przybliżyła słuchaczom „Formacyjny wymiar Światowych Dni Młodzieży”. Kolejny prelegent zaprezentował temat „Dobro i rozwój człowieka ideą Światowych Dni Młodzieży”. Po wystąpieniach ks. A. Kiciński otworzył dyskusje, w której jako pierwszy zabrał głos o. prof. dr hab. Andrzej Potocki OP. Odnosząc się do wystąpienia ks. A. Spałka, zasugerował w przyszłości prezentację tak bogatego zebranego materiału zgodnie z własną koncepcją interpretacyjną, co byłoby dodatkowym walorem. Prelegent podziękował za tę sugestię jednocześnie wyjaśniając, iż podejmowane przez niego zagadnienie jest niezmiernie szerokie, w związku z czym - na potrzeby wystąpienia - ograniczył je do jednego aspektu, dobra i rozwoju człowieka. Po tym wyjaśnieniu głos zabrał ks. prof. dr hab. Stanisław Kulpaczyński

1 Do czasu wydania 11 tomu „Studiów Katechetycznych” nominacje profesorskie otrzymali kolejni członkowie Stowarzyszenia - ks. prof. dr hab. Radosław Chałupniak oraz ks. prof. dr hab. Wojciech Cichosz.

2 Wszystkie wystąpienia zostały opublikowane w tym numerze „Studiów Katechetycznych” w dziale „Artykuły”. 
sdb. Wpierw przyznał, iż rzeczywiście warto by było we wstępie zadać pytanie problemowe, ze swej strony jednak podkreślił znaczenie pytania zawartego w ostatniej części wystąpienia. Oczekując na odpowiedź powtórzył za prelegentem - co należy uczynić, by katecheza i duszpasterstwo jak najwięcej skorzystały ze Światowych Dni Młodzieży? Jak przy tym stwierdził, zależeć to będzie od wiązania studiów i refleksji naukowej z konkretnymi działaniami w praktyce duszpasterskiej i katechetycznej. $Z$ odpowiedzią pośpieszyła p. E. Tkocz przyznając, iż łączenie teorii z praktyką jest niezmiernie istotne. $\mathrm{O}$ ile bowiem materiały praktyczne są często bardzo dobrze opracowane przez kompetentne osoby, o tyle nie zawsze docierają do bezpośrednich zainteresowanych ich wykorzystaniem.

Kolejnym punktem sympozjum była Msza święta, której przewodniczył ks. bp Henryk Tomasik, zaś homilię wygłosił ks. Piotr Tomasik. Zwracając się do członków Stowarzyszenia Katechetyków Polskich podkreślił, jak istotne winno być dla nich słuchanie Słowa Bożego i jego realizacja w codzienności. Po Mszy świętej sesji popołudniowej przewodniczyła s. Anna dr hab. Walulik, sekretarz SKP. Zaproszonym do tej części prelegentem był ks. bp Damian Muskus, który w swym wystąpieniu przybliżył, jak „Kościół w Polsce przygotowuje Światowe Dni Młodzieży”. Po tej prelekcji nastąpił panel dyskusyjny, o którego poprowadzenie poproszono o. A. Potockiego. Uczestnikami panelu byli zaś: ks. prof. dr hab. Janusz Mastalski, ks. bp dr Henryk Tomasik, ks. dr hab. Andrzej Kiciński prof. KUL, ks. dr Mirosław Chmielewski CSSR. Tytułem wprowadzenia o. A. Potocki zwrócił uwagę na hasło panelu, zawierające dwa istotne pojęcia - katechezę oraz Światowe Dni Młodzieży. Zarówno katecheza, jak i ŚDM charakteryzuje występowanie pewnego stałego elementu, a równocześnie element zmienny, zależny od różnych czynników i okoliczności. Po tej krótkiej refleksji prowadzący poprosił każdego z uczestników o odniesienie się do następujących kwestii: 1. ŚDM - między akcją a formacją; 2. ŚDM jako doświadczenie i wyzwanie oraz 3. ŚDM jako fakt medialny.

Do pierwszej postawionej kwestii odniósł się wpierw ks. bp Henryk Tomasik. Przypomniał pewne fakty związane z ustanowieniem ŚDM oraz przedstawił cztery dynamizmy ożywiające fenomen inicjatywy. W swej wypowiedzi wykazał, iż SDM przekraczają zdecydowanie akcję, ponieważ towarzyszy im opracowywanie programów i spotkań, a to ma charakter formacyjny. Z taką opinią zgodził się ks. A. Kiciński dodając, iż w przypadku ŚDM rolę katechetów przyjmują biskupi, co jest nie bez znaczenia. Podkreślił przy tym prymat Słowa Bożego wyznaczający rytm i cel spotkań i specyficzną eklezjologię, w myśl której spotkania odbywają się zarówno w Kościele powszechnym - z Ojcem Świętym, jak i lokalnych wspólnotach, gdy młodzież spotyka się w diecezjach $\mathrm{z}$ własnymi pasterzami. Kończąc swą wypowiedź podkreślił, iż dzięki zaangażowaniu wielu osób Światowe Dni Młodzieży nie ograniczają się do akcji, ale stanowią rodzaj formacji. Nowy wątek do dyskusji wprowadził ks. prof. dr hab. Janusz Mastalski, przestrzegając przed zbędnym przeciwstawianiem dwóch terminów: akcja i formacja, skoro niemal każda formacja zakłada na początku jakiś rodzaj akcji (choć - jak dodał - nie każda akcja przeradza 
się w formację). Zauważył przy tym, iż w dzisiejszych czasach szczególnie trudno prowadzić jakąkolwiek formację, o ile nie rozpocznie się jej akcją. Ważne jest jednak, by dzieło było kontynuowane - tak, jak słowa Jezusa nie tylko mają być wysłuchane, ale także dopełnione konkretnym działaniem. Bez osobistego odczytania orędzia, zaangażowania i pracy nad sobą, istnieje ryzyko, iż ŚDM pozostaną jedynie akcją, bez jakiegokolwiek wymiaru formacyjnego. Kwestię osobistego przyjmowania słowa Bożego i zaangażowania podjął również o. Mirosław Chmielewski, choć odniósł je do katechetów i duszpasterzy. Podkreślił, iż to właśnie ich mentalne nastawienie i świadomość zdecydują o tym, czy ŚDM pozostaną akcją, czy też przerodzą się w formację. Znaczna część katechetów i duszpasterzy skupia się na podejmowaniu efektownych akcji, lecz one nie mają nic wspólnego z formacją. O. Mirosław zwrócił też uwagę na charakterystyczny dla naszych czasów napływ informacji - również odnośnie do ŚDM nie brakuje ich, jednak potrzeba konkretnej pracy katechetów i duszpasterzy, by te informacje mogły przełożyć się na formację - tak katechetów, jak i młodzieży.

Po wysłuchaniu wszystkich wypowiedzi dotyczących pierwszego zagadnienia, o. Potocki poprosił uczestników panelu o odniesienie się do kwestii drugiej - doświadczeń i wyzwań związanych ze Światowymi Dniami Młodzieży. Jako pierwszy zabrał głos ks. J. Mastalski, wyliczając konkretne problemy dzisiejszej młodzieży, których nie można pominąć w kontekście ŚDM i przygotowań do nich. Te problemy to: 1. depersonalizacja człowieka i jego relacji, 2. pauperyzacja mistrzów, autorytetów; 3. despirytualizacja życia, pozbawienie duchowości; 4. deaksjologizacja wyborów, 5. „flanelizacja” edukacji, 6. brutalizacja życia, 7. deewangelizacja rodzin, środowisk lokalnych, 8. manipulacja, 9. osamotnienie. Uwzględnienie tychże problemów pozwoli młodzieży dostrzec Kościół jako ich drogę. O. Chmielewski zobrazował wpierw doświadczenia i wyzwania wspomnieniem z rekolekcji oazowych, po czym wyjaśnił, iż doświadczenia z ŚDM są niezwykle różnorodne, a wyzwaniem niewątpliwie jest poważne potraktowanie wydarzenia przez osoby odpowiedzialne za różne wspólnoty działające w parafii. Podkreślił również istotne możliwości szkolnych rekolekcji wielkopostnych w zakresie programowej formacji do ŚDM i budowania poczucia wspólnoty całego Kościoła. Ks. bp H. Tomasik w tym samym temacie odniósł się do własnych doświadczeń, zaś za kluczowe wyzwania uznał: doświadczenie wspólnoty, pogłębienie współpracy księży i wiernych świeckich, świadectwo wiary, kształtowanie ducha ofiary, wolontariat i modlitwę o powołania dla konkretnej diecezji. Nade wszystko zaś podkreślił potrzebę pogłębiania u młodzieży świadomości Kościoła powszechnego. Podobnie jak przedmówcy, tak i ks. A. Kiciński odwołał się do własnego doświadczenia udziału w ŚDM. Jak zauważył, każde tego typu spotkanie dostarcza wielu doświadczeń, a uczestnicy wzajemnie ubogacają się. Przekazywanie innym tego, co się posiada, dotyczy także sfery materialnej. Omawiając zaś wyzwania ŚDM, wymienił słuchanie słowa Bożego w pierwszej osobie i dokładne zapoznawanie się z wypowiedziami Magisterium Kościoła. Jak zauważył, konkretne wyzwania będą dotyczyły także katechetów 
i duszpasterzy, którzy powinni pamiętać, by w swej działalności nie lekceważyli doświadczeń swych poprzedników. Pozostawianie organizacji ŚDM jedynie młodszym kapłanom pozbawia jakże cennego bagażu doświadczeń, pochodzącego z udziału w spotkaniach lub ich organizacji w poprzednich latach.

„SDM jako fakt medialny” były trzecim zagadnieniem, do którego odnosili się uczestnicy panelu. Na wstępie o. Chmielewski potwierdził sugerowaną przez o. Potockiego potrzebę specjalnego przygotowania dziennikarzy, którzy mieliby przekazywać informacje dotyczące Światowych Dni Młodzieży. Zachęcił również, by nie obawiać się mediów publicznych, lecz dołożyć wszelkich starań, by wypowiadały się tam osoby kompetentne, dobrze przygotowane do różnego rodzaju wypowiedzi. Ks. bp H. Tomasik zauważył, iż konieczne jest promowanie ŚDM w mediach, przy czym winna to być dobra promocja, bowiem dotyczy nie tylko samego wydarzenia, ale także w pewien sposób stanie się promocją kraju i kultury polskiej. Zaapelował również, by przekazywać prawidłowe dane, ponieważ sam wielokrotnie spotkał się z mieszaniem dat i numeracji ŚDM. Ks. Kiciński ze swej strony zaznaczył, iż przed każdym z wielkich ŚDM nie brakowało krytycznych kampanii medialnych zmierzających do zniechęcenia młodzieży od udziału. Mając tę świadomość warto zawczasu przygotować się na wszelkie ataki, jednocześnie dostrzegając wielki potencjał katolickich mediów i sekcji programów. Niezależnie bowiem od wszystkiego, wejście do świata mediów jest konieczne. Na jeszcze inny aspekt zagadnienia zwrócił uwagę ks. Mastalski - zachęcił do wchodzenia $\mathrm{w}$ dialog z przedstawicielami różnych mediów, upatrując się $\mathrm{w}$ tym szansy na powrót niektórych z nich do wspólnoty Kościoła. Obecność w mediach przy okazji ŚDM dostrzegł więc jako możliwość ewangelizacji. Ponadto przedstawił obszary kształcenia dziennikarzy, którzy niezależnie od koncernu, pozostają sługami słowa i muszą tę misję pełnić odpowiedzialnie.

Po wszystkich wypowiedziach uczestników panelu dyskusyjnego, głos przekazano wcześniejszym prelegentom, a wszystkich uczestników zachęcono do zadawania pytań. Wpierw p. E. Tkocz w odpowiedzi na pytanie, co katecheza zawdzięcza Światowym Dniom Młodzieży, stwierdziła, iż same te dni i udział w nich stanowią formę katechezy. Jednocześnie podkreśliła, jak wiele katecheza - zarówno parafialna, jak i szkolne nauczanie religii - ma do zaoferowania ŚDM. Następnie ks. bp D. Muskus podziękował za możliwość udziału w sympozjum i zapewnił, iż wszelkie uwagi i sugestie notował, by wykorzystać je w działaniach na rzecz ŚDM w Krakowie. Powracając zaś do tematu ŚDM jako faktu medialnego stwierdził, iż zakładają dobrą współpracę, co nie wyklucza potrzeby należytego przygotowania dziennikarzy. Zauważył przy tym, iż w zdecydowanej mierze media pokażą to, co Kościół przygotuje, zatem warto skupić się na właściwym wypełnieniu własnych zadań. Zachęcił do podejmowania różnorodnych akcji na rzecz Światowych Dni Młodzieży, pamiętając jednak o ich związku z wewnętrzną formacją osób zaangażowanych. Podsumowując zaś dostrzegł, iż najlepszym sprawdzianem przygotowania 
ŚDM będzie to, co po nich zostanie - trzeba zatem przygotować je w taki sposób, by trwały w młodzieży i przynosiły dobre owoce.

Po tych wypowiedziach, głos zabrał ks. dr hab. Stanisław Łabendowicz, dzieląc się refleksją nad pięknem idei Światowych Dni Młodzieży z ich charakterystycznymi elementami - słowem Bożym, chrystocentrycznym odniesieniem, hasłami spotkań, wymiarem biblijnym przeżywanym z całym Kościołem, doświadczeniem piękna młodego Kościoła, związku z liturgią, kształtowaniem postaw apostolskich. Tak realizowane ŚDM nie tylko wiążą się z katechezą, ale wzajemnie z nią uzupełniają. Następnie ks. dr Artur Filipiak, redaktor naczelny miesięcznika „Katecheta” zaapelował o lepszy przepływ wiadomości katechetycznych i duszpasterskich, również związanych z ŚDM. Jednocześnie wysunął wniosek, by to właśnie Stowarzyszenie Katechetyków Polskich było środowiskiem, które będzie upowszechniać te informacje. Wobec braku innych głosów, s. A. Walulik podziękowała wszystkim za wypowiedzi i przypomniała dalszy program sympozjum. Zgodnie z nim, wieczorem miała nastąpić prezentacja nowych publikacji katechetycznych. Tak, jak to ustalono, autorzy i redaktorzy przedstawili wydane od ostatniego sympozjum książki naukowe i czasopisma. Przedstawiciele redakcji zapraszali do współpracy i nadsyłania artykułów. Po zapoznaniu się z nowościami na rynku katechetycznym, uczestnicy sympozjum udali się na spotkanie koleżeńskie, celem integracji środowisk.

Kolejny dzień sympozjum - 24 września - rozpoczęto Mszą świętą, w czasie której przewodniczył i homilię wygłosił ks. bp dr Marek Mendyk, przewodniczący Komisji Wychowania Katolickiego Konferencji Episkopatu Polski. Przypomniał on trudy głoszenia Chrystusa w dzisiejszym świecie, podkreślając przy tym nadzieje pokładane w katechetach katechetykach. Następnym ważnym punktem spotkania było walne zebranie Stowarzyszenia Katechetyków Polskich. Na wstępie s. A. Walulik odczytała sprawozdanie z ubiegłorocznego walnego zebrania i sprawozdanie z działalności zarządu SKP za rok 2013. W dalszej części o. A. Potocki przedstawił sprawozdanie z działalności Komisji Rewizyjnej, zgłaszając uwagi poczynione przez tę Komisję. Po odczytaniu dokumentu, przyjęto sprawozdania. Po tych formalnościach omówiono zasady współpracy Stowarzyszenia z redakcją „Studiów Katechetycznych”, zaś ks. A. Filipiak podziękował członkom Stowarzyszenia za ich zaangażowanie, dzięki któremu miesięcznik „Katecheta” odzyskał punktację. Zapowiedział pewne zmiany w czasopiśmie i raz jeszcze zachęcił do dzielenia się informacjami.

W dalszej części walnego zebrania poproszono o autoprezentację nowych członków, po czym dokonano wyboru logo SKP spośród nadesłanych propozycji. Przewodniczący Stowarzyszenia, ks. prof. dr hab. Z. Marek przypomniał zasady postępowania wobec osób, które dwukrotnie nie będą uczestniczyły w walnym zebraniu oraz wykażą zaległości w regulowaniu składek członkowskich. W ramach wolnych wniosków ks. dr Roman Buchta przekazał informacje o europejskich spotkaniach katechetycznych - stowarzyszenia EUFRES oraz Europejskiej Ekipy Katechetycznej, a dr A. Rayzacher-Majewska - jako opiekun Koła Naukowego 
Katechetyków UKSW - zachęciła do współpracy z tą organizacją studencką i uzyskania statusu sympatyka Koła. Na zakończenie walnego zebrania podjęto kwestię ubogacenia strony internetowej Stowarzyszenia. Sekretarz SKP, s. A. Walulik zaproponowała, by wszelkie informacje o odnoszonych sukcesach i planowanych wydarzeniach nadsyłać do niej lub do ks. R. Chałupniaka. Po tych ustaleniach ks. Z. Marek podał termin kolejnego sympozjum Stowarzyszenia oraz zamknął posiedzenie.

Jak zwykle przy okazji wrześniowego sympozjum, przekazane zostały informacje o aktualnych problemach związanych z organizacją katechezy. Uczynili to ks. bp Marek Mendyk oraz ks. prof. dr hab. Piotr Tomasik, zapowiadając wpierw spotkanie w sprawie nowelizacji porozumienia KEP i MEN w sprawie kwalifikacji nauczycieli religii. Poruszono także kwestie dotyczące umieszczenia religii poza ramowymi planami nauczania. Ks. bp M. Mendyk zaapelował, by wszelkie zastrzeżenia odnośnie do nauczania religii w przedszkolach i szkołach były zgłaszane na piśmie, co umożliwi uwzględnianie ich w kontaktach z MEN. Z kolei ks. dr Marek Korgul, sekretarz Komisji Wychowania Katolickiego przedstawił problemy związane z umieszczaniem religii na pierwszej lub ostatniej godzinie, łączeniem klas, możliwością udziału w zajęciach z religii i/lub etyki oraz ocen z tychże przedmiotów. Przypomniano aktualne zobowiązania odnośnie do deklaracji udziału uczniów w lekcjach z religii oraz minimalne ilości uczniów w oddziałach klasowych, szkolnych i międzyszkolnych. Na zakończenie ks. bp M. Mendyk poinformował o zgodzie MEN na pozyskiwanie informacji o nauczaniu religii w ramach Systemu Informacji Oświatowej. Była to dobra informacja w kontekście nadchodzącego 25lecia religii w szkołach. Zapewnił także, iż strona kościelna w kontaktach z MEN będzie powracać do kwestii matury z religii, choć Ministerstwo nie wykazuje zrozumienia dla tego tematu.

Po przekazaniu tych informacji, uczestnicy sympozjum mieli możliwość zadania pytań dotyczących szczegółowych problemów wynikających z praktyki katechetycznej. Pojawiły się więc zagadnienia takie jak przekazywanie parafii danych nt. udziału uczniów w lekcjach religii, zatrudnianiem nauczycieli od 2 września i wpisywania w arkusze niewiadomej ilości godzin lekcji religii. Sam przewodniczący Komisji Wychowania zaapelował o czujność względem osób podejmujących w szkołach edukację seksualną.

Ostatnie chwile sympozjum upłynęły na poszukiwaniu tematu przyszłorocznych obrad. Nie brakowało różnorodnych propozycji, dotyczących m.in. 25-lecia wprowadzenia religii do szkół, Synodu Biskupów o rodzinie czy teorii katechetyki. Ostatnia porpozycja zyskała szczególnie wielu zwolenników. Podsumowując wszystkie propozycje, przewodniczący SKP ostatecznie ogłosił roboczy temat kolejnego spotkania „Teoria katechetyki”. Nie wykluczył przy tym zaproszenia przedstawicieli katechetyki z innych krajów zapewniając przy tym, iż wszelkie szczegóły dotyczące sympozjum będzie przekazywał na bieżąco. Poprosił też o zgłaszanie się prelegentów zainteresowanych wystąpieniem na sympozjum w roku 2015. Na 
zakończenie podziękował wszystkim - zarówno prelegentom, jak i słuchaczom, a także swoim współpracownikom odpowiedzialnym za organizację i przebieg spotkania. Zanim wszyscy udali się do swoich ośrodków naukowych, wspólną modlitwą podziękowali za możliwość spotkania, wypraszając Bożego błogosławieństwa dla dalszych poczynań naukowych. 